\title{
Сжиженный газ - альтернативный источник поставок природного газа в промышленно развитые регионы мира
}

\author{
Т. В. Дьяченко ${ }^{1}$, В. Н. Артюх ${ }^{2}$, А. С. Титлов ${ }^{3}$ \\ Одесская национальная академия пищевых технологий, ул. Канатная, 112, г. Одеса, 65039, Украина \\ e-mail: ${ }^{1}$ diachenko.tetiana.v@gmail.com, ${ }^{2}$ vartiuh@ outlook.com, ${ }^{3}$ titlov1959@ gmail.com \\ ORCID: ${ }^{1}$ http://orcid.org/0000-0001-9275-187X; ${ }^{2}$ http://orcid.org/0000-0002-1751-7933; ${ }^{3}$ http://orcid.org/0000-0003-1908-5713

\begin{abstract}
Природный газ является ценным энергоносителем, а также сырьем для химической промышленности. В работе приведены данные по мировому рынку природного газа с учетом сжиженного природного газа: запасы, производство, потребление. Показано, что поставки сжиженного природного газа являются альтернативой для газоснабжения развитых стран и труднодоступных для газоснабжения регионов, а снижение удельного энергопотребления на производство сжиженного природного газа сделает эту отрасль более доступной для потребителей.
\end{abstract}

Ключевые слова: Природный газ; Сланцевый газ; Рынок природного газа; Сжиженный природный газ

\section{Зріджений газ - альтернативне джерело поставок природного газу в промислово розвинені регіони світу}

\author{
Т. В. Дьяченко, В. М. Артюх, О. С. Титлов
}

Одеська національна академія харчових технологій, вул. Канатна, 112, м Одеса, 65039, Україна

\begin{abstract}
Природний газ є иінним енергоносієм, а також сировиною для хімічної промисловості. В роботі наведено дані щуодо світового ринку природного газу з урахуванням зрідженого природного газу: запаси, виробництво, споживання. Показано, щуо поставки зрідженого природного газу є альтернативою для газопостачання у розвинені країни та важкодоступні для газопостачання регіони, а зниження питомого енергоспоживання на виробниичтво зрідженого природного газу зробить иฺю галузь більш доступною для споживачів.
\end{abstract}

Ключові слова: Природний газ; Сланцевий газ; Ринок природного газу; Зріджений природний газ

DOI: http://dx.doi.org/10.15673/ret.v53i2.595

(C) The Author(s) 2017. This article is an open access publication

This work is licensed under the Creative Commons Attribution 4.0 International License (CC BY) http://creativecommons.org/licenses/by/4.0/

\section{Введение}

Природный газ (ПГ) - ценное сырье для народного хозяйства. Он используются для отопления жилых помещений, приготовления пищи, производства энергии и в качестве топлива на транспорте. Кроме этого, ПГ является важнейшим сырьем для химической промышленности - синтеза водорода, аммиака, минеральных удобрений, метанола и т.п.

Для поставок природного газа на большие расстояния, как правило, используют инфраструктуру на основе трубопроводов большого диаметра. Снабжение ПГ промышленных объектов, расположенных в труднодоступных или удаленных областях, где строительство газопровода технически или экономически нецелесообразно, производится путем поставок сжиженного газа.

В настоящее время доля сжиженного природного газа (СПГ) составляет около $18 \%$ от используемого природного газа и продолжает расти [1]. Ценность процесса получения СПГ заключается не только в организации поставок потребителям, но и возможности полу- чения в промышленных объемах концентрата гелия, пригодного к переработке.

Сжижение природного газа - это не только сложный, но и затратный процесс. Объемы его производства достигают 338,3 млрд. м³ за 2015 год [4].

Реализация поставок СПГ требует значительных капитальных вложений на строительство установок для сжижения природного газа и приемных терминалов, которые позволяют его хранить и использовать. Снижение энергозатрат при получении и регазификации СПГ, разработка и внедрение новых, более экономичных технологий находятся в русле общего направления развития мировой экономики, направленного на снижение энергопотребления в экономике.

\section{1 Источники природного газа}

1.1 Компонентный состав природного газа. Как известно, природный газ - это смесь углеводородных газов, основным компонентом которого является метан. В местах добычи перед транспортировкой из ПГ извле- 
кают тяжелые углеводороды и негорючие газы, которые используются для отопления домов, в качестве автомобильного топлива, а также для производства нефтехимической продукции.

В зависимости от содержания метана и других углеводородных компонентов метанового ряда газы делятся на сухие, жирные и кислые (рисунок 1 ). К сухим относятся газы, в которых содержание метана составляет 95-96 \%, а этана, пропана, бутана и пентана незначительно (доли процента). Такие составы характерны для чисто газовых залежей, где отсутствуют источники обогащения тяжелыми компонентами.

Жирные газы - это газы с высоким содержанием «тяжелых» соединений. Помимо метана, в них содержатся десятки процентов этана, пропана и более высокомолекулярных соединений вплоть до гексана. Жирные газовые смеси характерны для попутных газов, сопровождающих нефтяные залежи.
Кислые газы - это газы с высоким содержанием $\mathrm{CO}_{2}$.

Природный газ в качестве топлива обладает высокой теплотворной способностью, хорошей транспортабельностью, большей по сравнению с нефтью и углем экологической чистотой. Его главная ценность заключается в том, что это - экологически чистое минеральное топливо, при сгорании которого образуется малое количество вредных соединений. Все это создает предпосылки для наращивания использования ПГ в коммунальном хозяйстве, в промышленности, включая электроэнергетику, на транспорте. Доля природного газа в структуре мирового энергопотребления постоянно увеличивается.

В зависимости от состава природного газа применяются различные технологии подготовки к транспортировке. Этот же критерий определяет себестоимость природного газа для потребителей.

Сухой Газ месторождение Уренгой, Медвежье

Жирный газ месторождение Уренгой, Ямбургское

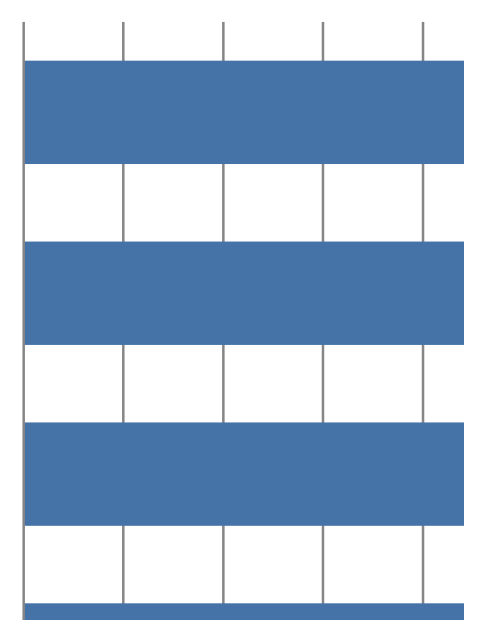

Рисунок 1 - Состав газа различных источников

1.2 Распределение залежей природного газа. Мировые доказанные запасы газа, на конец 2015 г. составляют 186,9 трлн. м ${ }^{3}$ [4]. Они распределены неравномерно (рисунок 2). Наибольшие по объему месторождения ПГ находятся в России (17\%), Иране (18\%) и Катаре (13\%). На постсоветской территории крупнейшими месторождениями природного газа обладают Узбекистан, Азербайджан, Казахстан (Карачаганакское месторождение) и Туркмения [4].

Основные залежи в России сосредоточены в ВолгоУральском, Тимано-Печорском и Западно-Сибирском газоносных регионах, а также на Дальнем Востоке и Северном Кавказе. Ниже дано краткое описание наиболее перспективных месторождений.

Уренгойское месторождение по величине пластовых запасов природного газа занимает второе место в мире. Оно располагается в Ямало-Ненецком АО Тюменской области. Добычу природного газа из этого месторождения начали в 1978 году.

Находкинское месторождение расположено в Большехетской впадине Ямало-Ненецкого АО. Его разработка стартовала в 2004 году. Согласно оценке экспертов, газовые запасы в этом месте превышают 275 миллиардов кубометров.

Ангаро-Ленское месторождение было открыто в начале XXI столетия. Располагается в Иркутской обла- сти, вблизи рек Ангары и Лены, в соответствии с которыми ему и дано название. Запасы природного газа составляют примерно 1,4 триллиона кубометров.

Ковыктинское месторождение расположено в 450 км к северо-востоку от города Иркутск, на высокогорном плато, которое покрывает темнохвойная тайга. Климатические условия в данном районе весьма суровые. Часть территории находится в районе многолетней мерзлоты. Большое количество каньонов осложняют рельеф этой местности. Величина запасов природного газа достигает двух триллионов кубометров и 120 миллионов тонн жидкого газового конденсата.

Штокманское газоконденсатное месторождение является одним из самых крупномасштабных в мире. Его открыли в 1988 году. Расположение - центральная часть шельфа Баренцева моря, ориентировочно в 600 км к северо-востоку от города Мурманск. Объем газовых запасов составляет 3,8 триллиона кубометров. В связи с большой глубиной залегания газа, а также затруднительными условиями разработки, добыча здесь еще не ведется. Реализация проекта по получению ПГ требует высокотехнологичного оборудования и значительных затрат.

Одновременно с потреблением ПГ производятся постоянные геофизические изыскания, которые открывают новые месторождения (рисунок 3). Например, объем 
разведанных запасов ПГ по сравнению с уровнем двадцатилетней давности (119,9 трлн. м³ на конец 1995 г.) вырос на 55,9\%, а если сравнивать с уровнем десятилетней давности (157,3 трлн. м ${ }^{3}$ на конец 2005 г.) - на
18,9\% [4]. Самыми большими доказанными запасами 80 млрд. м ${ }^{3}$, обладают страны Среднего Востока: Катар, Иран, Саудовская Аравия.
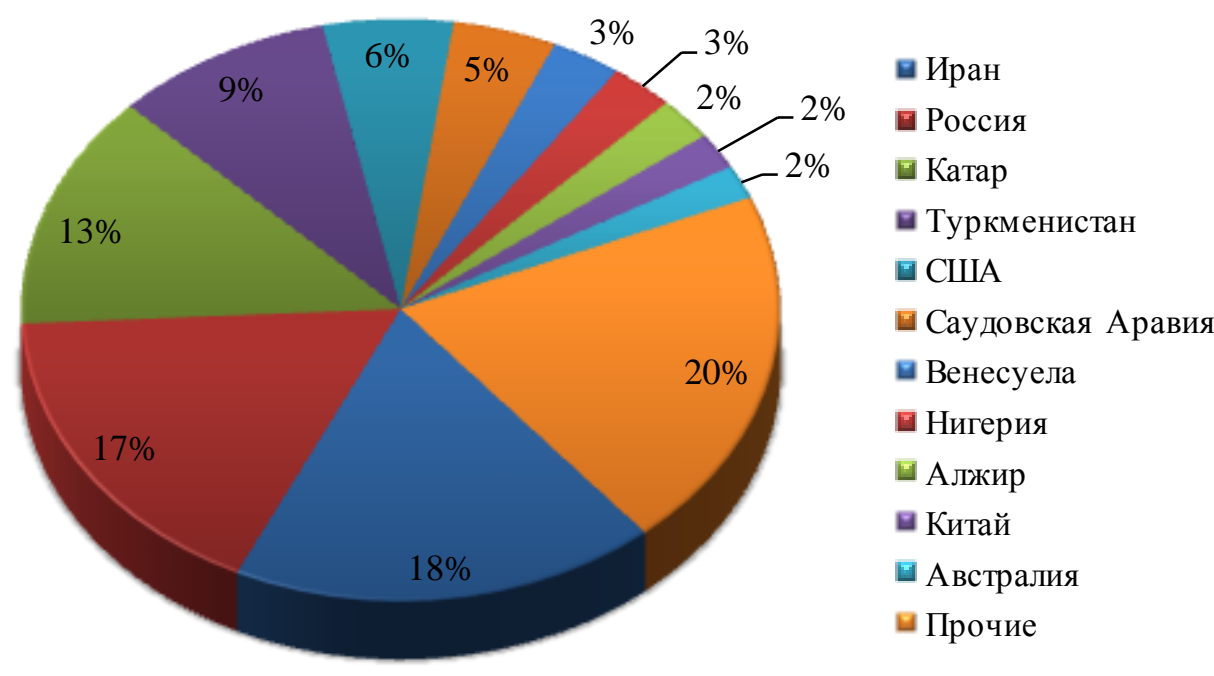

Рисунок 2 - Распределение мировых запасов ПГ на 2015 год

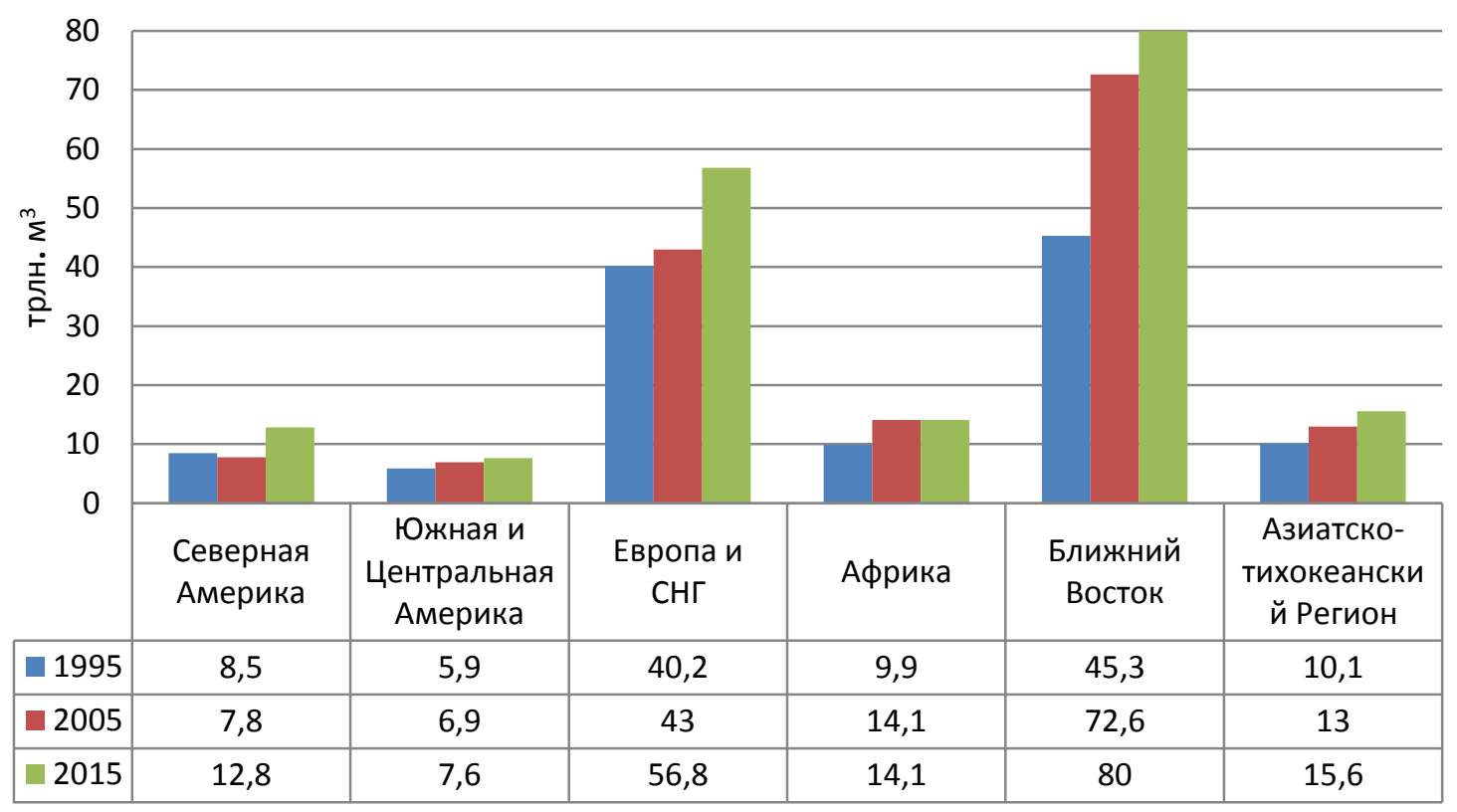

Рисунок 3 - Распределение доказанных запасов природного газа в 1995, 2005 и 2015 годах по регионам [4]

В таблице 1 приведены данные о доказанных запасах природного газа на территории Европы с учетом России. Первыми промышленными месторождениями, из которых начали добывать природный газ, были национальные газовые месторождения в Южной Франции, Северной Италии, Германии и Румынии [5]. В 1960-е годы в Нидерландах было найдено большое газовое месторождение Гронинген.

Анализ таблицы 1 еще раз показывает, что самые большие запасы природного газа размещены на территории России (32,3 трлн. м ${ }^{3}$ ) [4]. Вторые по объему $\left(1,9\right.$ трлн. $\left.{ }^{3}\right)$ запасы в Норвегии.
1.3 Сланцевый газ. В последние десятилетия бурными темпами развивается добыча сланцевого газа (СГ) [7]. По составу это преимущественно метан, однако его достаточно трудно извлечь. Для этого необходимо снимать большие по площади объемы почвы. Это очень затратный и экономически нерентабельный способ добычи. Тем не менее, технологии не стоят на месте, а себестоимость его добычи постоянно снижается.

Анализ разведанных запасов СГ в мире (таблица 2) показывает, что самыми большими запасами технически доступного сланцевого газа обладают Китай, США, Мексика и Аргентина. 
Taблица 1 - Доказанные запасы ПГ Европы [4]

\begin{tabular}{|c|c|c|c|c|}
\hline \multirow{2}{*}{ Страны } & \multicolumn{2}{|c|}{ Доказанные запасы } & \multicolumn{2}{|c|}{ Производство } \\
\cline { 2 - 5 } & трлн. $^{3}$ & $\%$ & млрд. $^{3}$ & 4,6 \\
\hline Дания & $0,05<$ & $0,05<$ & 7,2 & 0,1 \\
\hline Германия & $0,05<$ & $0,05<$ & 6,2 & 0,2 \\
\hline Италия & $0,05<$ & $0,05<$ & 43 & 1,2 \\
\hline Голландия & 0,7 & 0,4 & 117 & 3,3 \\
\hline Норвегия & 1,9 & 1 & 4,1 & 0,1 \\
\hline Польша & 0,1 & 0,1 & 10,3 & 0,3 \\
\hline Румыния & 0,1 & 0,1 & 573,3 & 16,1 \\
\hline Россия & 32,3 & 17,3 & 17,4 & 0,5 \\
\hline Украина & 0,6 & 0,3 & 39,7 & 1,1 \\
\hline Англия & 0,2 & 0,1 & 3,2 & 0,1 \\
\hline Другие & 0,1 & 0,1 & & \\
\hline
\end{tabular}

Таблица 2 - Распределение запасов сланцевого газа [9]

\begin{tabular}{|c|c|c|c|c|c|}
\hline \multirow[t]{2}{*}{ Страна } & \multicolumn{2}{|c|}{ 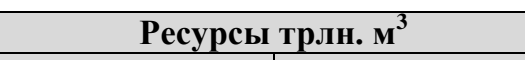 } & \multirow[t]{2}{*}{ Страна } & \multicolumn{2}{|c|}{ 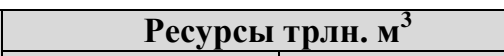 } \\
\hline & Геологические & $\begin{array}{c}\text { Tехнически } \\
\text { извлекаемые }\end{array}$ & & Геологические & $\begin{array}{l}\text { Технически } \\
\text { извлекаемые } \\
\end{array}$ \\
\hline \multicolumn{3}{|c|}{ Северная Америка } & \multicolumn{3}{|c|}{ Европа } \\
\hline Канада & 68,34 & 16,23 & Великобритания & 3,8 & 0,74 \\
\hline США & 78,30 & 18,80 & Германия & 2,27 & 0,48 \\
\hline Мексика & 63,24 & 15,43 & Дания & 4,5 & 0,91 \\
\hline \multicolumn{3}{|c|}{ Южная и Центральная Америка } & Испания & 1,19 & 0,23 \\
\hline Аргентина & 91,87 & 22,71 & Нидерланды & 4,28 & 0,74 \\
\hline Боливия & 4,36 & 1,02 & Франция & 20,59 & 3,88 \\
\hline Бразилия & 36,22 & 6,94 & Швеция & 1,39 & 0,28 \\
\hline Венесуэла & 23,08 & 4,73 & Болгария & 1,87 & 0,48 \\
\hline Колумбия & 8,72 & 1,56 & Литва & 0,11 & - \\
\hline Парагвай & 9,91 & 2,12 & Польша & 21,61 & 4,19 \\
\hline Уругвай & 0,37 & 0,06 & Румыния & 6,60 & 1,44 \\
\hline Чили & 6,46 & 1,36 & Украина & 16,20 & 3,62 \\
\hline & Азия & & Россия & 54,97 & 8,13 \\
\hline Индия & 16,54 & 2,72 & \multicolumn{3}{|c|}{ Африка } \\
\hline Индонезия & 8,58 & 1,30 & Алжир & 96,83 & 20,02 \\
\hline Иордания & 0,99 & 0,2 & Египет & 15,15 & 2,83 \\
\hline Китай & 134,41 & 31,58 & Ливия & 26,68 & 3,46 \\
\hline Монголия & 1,56 & 0,11 & Марокко & 2,69 & 0,57 \\
\hline Пакистан & 16,60 & 2,97 & Тунис & 3,23 & 0,65 \\
\hline Таиланд & 0,62 & 0,14 & ЮAP & 44,15 & 11,04 \\
\hline Турция & 4,62 & 0,68 & \multicolumn{3}{|c|}{ Австралия и Океания } \\
\hline \multirow{3}{*}{ Итого } & & & Австралия & \begin{tabular}{|l|}
57,94 \\
\end{tabular} & 12,38 \\
\hline & \multicolumn{2}{|c|}{ Геологические } & & \multicolumn{2}{|c|}{ Технически извлекаемые } \\
\hline & \multicolumn{2}{|c|}{960,84} & & \multicolumn{2}{|c|}{206,73} \\
\hline
\end{tabular}

Впервые на промышленном уровне СГ начали добывать в 1821 году вблизи Нью-Йорка. Сегодня самыми объемными месторождениями признаны Ред-Хок, Тикондерога, Тендер-Хорс, расположенные в Мексиканском заливе. По доказанным данным, здесь может находиться до 20 млрд. кубометров топлива.

Лидером по объемам залежей является месторождение на Аляске - Пойнт-Томпсон. По оценкам запасы сланцевого газа составляют более 3 триллионов кубометров. В настоящее время в США строят газопровод для подачи СГ в Вашингтон, окончание которого планируется в 2018 году. Это во многом решит энергетические проблемы Соединенных штатов Америки за счет собственных ресурсов.

\section{2 Производство природного и сланцевого газа}

История газовой промышленности, насчитывающая немногим более ста лет, подразделяется на два больших этапа. Первый из них продолжался до 50-60-х гг. XX в. [8]. Для него был характерен перевес одной страны США, доля которой в мировой добыче природного газа еще в 1950 г. превышала 9/10. Затем начался второй этап - этап быстрого роста добычи и потребления природного газа и формирования новых районов газовой промышленности: в СССР, Юго-Западной Азии, Западной Европе, Северной Африке и других регионах. Одновременно происходило формирование международного рынка природного газа. 
Производство природного газа постоянно увеличивается (рисунок 4, таблица 3). За период с 2005 по 2015 гг. уровень производства вырос с 2790,9 млрд. м в 2005 до 3538,6 млрд. м³ в 2015 году (на 26,7\%) [4].

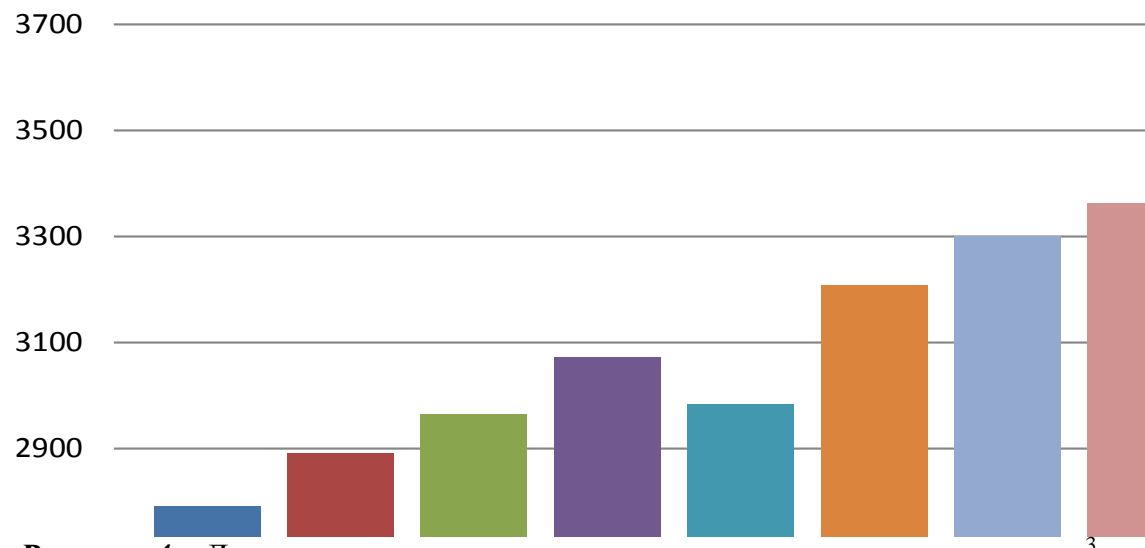

Рисунок 4 - Динамика мирового производства природного газа, млрд м ${ }^{3}$

Таблица 3 - Структура мирового производство природного газа по регионам за период 2005-2015 гг. [4]

\begin{tabular}{|c|c|c|c|c|c|c|c|c|c|c|c|}
\hline Регион & 2005 & 2006 & 2007 & 2008 & 2009 & 2010 & 2011 & 2012 & 2013 & 2014 & 2015 \\
\hline Северная Америка & 750,5 & 769,7 & 781,8 & 800,8 & 807,3 & 821,3 & 866,5 & 893,5 & 899,7 & 947,7 & 984 \\
\hline $\begin{array}{l}\text { Южная и Цен- } \\
\text { тральная Америка }\end{array}$ & 140,5 & 154,1 & 162,1 & 163,0 & 157,7 & 166,2 & 167,0 & 173,6 & 175,9 & 177,1 & 178,5 \\
\hline Европа и Азия & 1024,8 & 1037,3 & 1033,3 & 1062,7 & 942,7 & 1014,5 & 1025,5 & 1019,8 & 1026,5 & 996,5 & 989,8 \\
\hline Средний Восток & 321,0 & 343,7 & 372,7 & 400,7 & 422,2 & 495,6 & 528,8 & 554,7 & 587,5 & 599,1 & 617,9 \\
\hline Африка & 177,0 & 192,6 & 203,4 & 212,0 & 199,7 & 213,3 & 211,7 & 216,0 & 205,9 & 208 & 211,8 \\
\hline $\begin{array}{l}\text { Азиатско-Тихооке- } \\
\text { анский регион }\end{array}$ & 377,0 & 393,9 & 411,2 & 432,5 & 453,6 & 497,8 & 500,4 & 505,0 & 516,2 & 534,8 & 556,7 \\
\hline$\Sigma$ & 2790,9 & 2857,7 & 2969,2 & 3052,2 & 2971,1 & 3201,4 & 3249,2 & 3332,5 & 3392,9 & 3410,2 & 3538,6 \\
\hline
\end{tabular}

Анализ таблицы 3 показывает, что самым большим производителем природного газа в Европе является Россия, она же является самым большим поставщиком природного газа в ее Западную часть [4].

Второй по объему производства страной является Норвегия, которая потребляет всего два процента от объема его производства. Основное направление поставок норвежского газа - это Великобритания. За последнее время королевство поставило странам Европы около $30 \%$ потребленного ими газа.

\section{3 Структура потребления природного газа}

Объем потребления природного газа в мире незначительно отличается от объема его производства, поскольку почти весь добываемый и получаемый газ сра- зу же поступает в газораспределительные сети. В 2015 году объемы новых разведанных запасов сравнялись с уровнем потребления и достигли 186,9 трлн. м ${ }^{3}$ [4]. При современном уровне потребления этих запасов хватит для удовлетворения потребностей человечества на 52,8 лет.

Доля стран Запада в потреблении природного газа (около 50\%), относящихся к технологически развитым странам, больше, чем их доля в производстве, а доля развивающихся стран (17\%) и стран с переходной экономикой (33\%) - напротив, меньше [8]. В 1990-х гг. эти относительные показатели, хотя и медленно, но продолжали изменяться: в странах с переходной экономикой - в сторону сокращения, а в двух других группах стран - в сторону увеличения доли потребления.

Таблица 4 - Мировое потребление природного газа за период 2005-2015 гг. [4]

\begin{tabular}{|c|c|c|c|c|c|c|c|c|c|c|c|}
\hline Регион & 2005 & 2006 & 2007 & 2008 & 2009 & 2010 & 2011 & 2012 & 2013 & 2014 & 2015 \\
\hline Северная Америка & 782,1 & 778,0 & 813,8 & 821,5 & 815,9 & 849,6 & 870,6 & 903,3 & 927,0 & 947,1 & 963,6 \\
\hline $\begin{array}{l}\text { Южная и Цен- } \\
\text { тральная Америка }\end{array}$ & 123,5 & 135,4 & 142,5 & 143,4 & 136,8 & 150,8 & 151,5 & 160,6 & 165,8 & 169,5 & 174,8 \\
\hline Европа и Азия & 1093,5 & 117,2 & 1120,6 & 1132,7 & 1041,5 & 1116,0 & 1089,1 & 1071,6 & 1051,2 & 1006,4 & 1003,5 \\
\hline Средний Восток & 279,3 & 296,8 & 321,8 & 347,0 & 358,2 & 399,5 & 404,6 & 417,9 & 446,9 & 461,4 & 490,2 \\
\hline Африка & 85,1 & 89,6 & 96,7 & 100,7 & 99,6 & 107,2 & 114,2 & 123,4 & 122,9 & 128,4 & 135,5 \\
\hline $\begin{array}{l}\text { Азиатско-Тихооке- } \\
\text { анский регион }\end{array}$ & 410,8 & 440,8 & 473,8 & 506,0 & 519,2 & 578,4 & 619,1 & 655,8 & 678,4 & 697,4 & 701,1 \\
\hline$\Sigma$ & 2504,5 & 2579,4 & 2679,8 & 2753,7 & 2680,2 & 2886,7 & 2929,3 & 3005,8 & 3062,5 & 3081,5 & 3135,2 \\
\hline
\end{tabular}


Европейская газовая сеть строилась постепенно в течение последних 70 лет. Первоначально она была разработана вокруг национальных газовых месторождений в Южной Франции, Северной Италии, Германии и Румынии [5]. Крупномасштабный импорт газа из Норвегии, России и Алжира был организован в качестве основного источника поставок газа в 1980-х годах после двух нефтяных кризисов. В 1990-х годах газовая сеть была построена в Греции, Португалии и Ирландии. После 2000 года наблюдается акцент на подключении газового рынка Великобритании к норвежскому газу на континенте и объединение с газовыми сетями новых государства-членов ЕС. Созданы альтернативные российским каналы газоснабжения путем прокладки тру- бопроводов из Северной Африки и с побережья Каспийского моря.

В 2016 году спрос на природный газ в Европе увеличился на 4,3\% по сравнению с 2015 годом из-за холодной зимы и перехода с угля на газ в энергетическом секторе. При незначительном изменении внутреннего производства дополнительный спрос на европейский газ был удовлетворен увеличением импорта с использованием трубопроводного транспорта путем увеличения поставок из России и Алжира. В 2016 году началось ожидаемое увеличение поставок СПГ, но увеличение поставок было потреблено азиатскими и ближневосточными рынками, прежде чем оно достигло Европы (таблицы 5, 6).

Таблица 5 - Европейский рынок газа 2014-2016

\begin{tabular}{|c|c|c|c|}
\hline & 2014 & 2015 & 2016 \\
\hline Потребности Европы & 476 млрд. м ${ }^{3}$ & 496 млрд. м ${ }^{3}$ & 517 млрд. м ${ }^{3}$ \\
\hline Производство & 255 млрд. $\mathrm{m}^{3}$ & 248 млрд. м $^{3}$ & 246 млрд. м $^{3}$ \\
\hline Объём в хранилищах (Storage Inventory Change) & 7 млрд. м $^{3}$ & 6 млрд. $\mathrm{M}^{3}$ & 1 млрд. $\mathrm{M}^{3}$ \\
\hline Русский импорт & 148 млрд. м $^{3}$ & 160 млрд. м $^{3}$ & 172 млрд. м $^{3}$ \\
\hline Другой импорт трубой & 32 млрд. м $^{3}$ & 30 млрд. м ${ }^{3}$ & 49 млрд. м ${ }^{3}$ \\
\hline Потребление СПГ в Европе & 49 млрд. м $^{3}$ & 51 млрд. м ${ }^{3}$ & 50 млрд. м $^{3}$ \\
\hline
\end{tabular}

Tаблица 6 - Объем потребления природного газа странами Европы [4]

\begin{tabular}{|c|c|c|c|c|c|}
\hline \multirow[t]{2}{*}{ Страны } & \multicolumn{2}{|c|}{ Потребление } & \multirow{2}{*}{ Страны } & \multicolumn{2}{|c|}{ Потребление } \\
\hline & млрд. м $^{3}$ & $\%$ & & млрд. $\mathbf{m}^{3}$ & $\%$ \\
\hline Австрия & 8,3 & 0,2 & Литва & 2,3 & 0,1 \\
\hline Беларусь & 17,2 & 0,5 & Голландия & 31,8 & 0,9 \\
\hline Бельгия & 15,1 & 0,4 & Норвегия & 4,8 & 0,1 \\
\hline Болгария & 2,9 & 0,1 & Польша & 16,7 & 0,5 \\
\hline Чехия & 7,2 & 0,2 & Португалия & 4,3 & 0,1 \\
\hline Дания & 3,2 & 0,1 & Румыния & 10,3 & 0,3 \\
\hline Финляндия & 2,1 & 0,1 & Россия & 391,5 & 11,2 \\
\hline Франция & 39,1 & 1,1 & Словакия & 4,3 & 0,1 \\
\hline Германия & 74,6 & 2,1 & Испания & 27,6 & 0,8 \\
\hline Греция & 2,8 & 0,1 & Швеция & 0,9 & $0.05<$ \\
\hline Венгрия & 8,9 & 0,3 & Швейцария & 2,9 & 0,1 \\
\hline Ирландия & 4,2 & 0,1 & Турция & 43,6 & 1,3 \\
\hline Италия & 61,4 & 1,8 & Украина & 28,8 & 0,8 \\
\hline Англия & 68,3 & 2 & Другие & 7,6 & 0,2 \\
\hline
\end{tabular}

Такая степень зависимости от России беспокоит европейских потребителей. 28 членов торгового блока предложили снизить ее с помощью развития добычи сланцевого газа и нефти, инвестирования в новые проекты по доставке газа в Европу из стран Центральной Азии и Северной Африки.

Ученые подтверждают, что в недрах Старого Света имеются достаточные запасы сланцевого газа. Больше всего его в Швеции, Дании, Польше, Болгарии, Франции и Испании. Так, например, запасов Швеции может хватить на добычу газа в течение 250 лет. Сланцевый газ уменьшит использование такого традиционного для Европы энергоносителя как уголь и снизит выбросы углекислого газа в атмосферу. Однако технология добычи сланцевого газа до сих пор остается спорной, опасной и отчасти экспериментальной. Защитники природы высказывают тревогу по поводу использования слишком большого объема воды и химикатов, а также реальной угрозы локальных землетрясений.

\section{4 Сжижение природного газа как способ поста- вок в удаленные и труднодоступные регионы}

4.1 Мировой рынок СПГ. Сжиженный природный газ представляет собой жидкую многокомпонентную смесь легких углеводородов, основу которой составляет метан. Для получения СПГ природный газ вначале очищают от углекислого газа и сероводорода, затем осушают - удаляют влагу и очищают от ртути, затем отделяют фракцию $\mathrm{C}_{3}$ и более тяжелые углеводороды. Оставшийся газообразный метан, в зависимости от требований к продукции по калорийности, может в качестве примесей иметь 3-4\% этана, 2-3\% пропана, до 2\% бутанов и до 1,5\% азота. Если эту смесь метана с другими газами охладить примерно до температуры $-160^{\circ} \mathrm{C}$ при давлении чуть больше атмосферного (температура кипения чистого метана при атмосферном давлении $\left.161,5^{\circ} \mathrm{C}\right)$, то он превращается в жидкость. В настоящее время технология сжижения природного газа и его 
дальнейшего транспортирования уже вполне освоена. Она включает:

- месторождение природного или попутного нефтяного газа (в мировом масштабе они обеспечивают примерно 2/3 всех поставок, а остальную часть газа дают нефтеперерабатывающие заводы);

- завод по сжижению природного газа при температуре $-162{ }^{\circ} \mathrm{C}$ с емкостями для его временного хранения;

- терминал, где полученный СПГ загружают в специальные танкеры-газовозы (метановозы);

- терминал на месте назначения, где производится выгрузка доставленного СПГ;

- хранилище СПГ и станция по его регазификации;

- установки для подачи газа в сеть потребителя.

Начиная с 1970-х гг. в качестве нового фактора мирового энергетического хозяйства стал выступать сжиженный природный газ [8]. Интерес к этому энергоносителю был обусловлен многими причинами, в частности, наличием больших ресурсов природного газа во многих странах Азии, Африки и Латинской Америки, которые после добычи невозможно транспортировать по газопроводам в экономически развитые страны. При этом экспортные поставки СПГ сравнительно легко осуществимы и не требуют строительства дорогостоящих газовых магистралей. С точки зрения экономики главным преимуществом СПГ перед газообразным топливом является мобильность рынка и возможность более широкого выбора производителя.

Природный газ в сжиженном виде используют большое количество стран, однако их объемы, составляющие 55 млрд. м ${ }^{3}$ от общего объема потребления природного газа, не сопоставимы с традиционным методом доставки трубопроводным транспортом (около $13 \%$ от общего объема потребления ПГ).

Главными экспортерами СПГ были и остаются развивающиеся страны - в первую очередь Юго-
Восточной Азии, но также Африки и Юго-Западной Азии, тогда как доля экономически развитых стран в мировом экспорте не достигает и 1/10 (рис. 4) [8]. Основной экспорт из стран Юго-Восточной Азии в начале XXI в. обеспечивают Индонезия, Малайзия и Бруней, из Африки - Алжир и Нигерия, из Юго-Западной АзииКатар и Абу-Даби (ОАЭ). Среди стран Запада к числу экспортеров СПГ относятся только США (Аляска) и Австралия. Важно учитывать, что эта группа ведущих стран-экспортеров не остается неизменной. Уже на рубеже XX-XXI вв. в нее вошли еще несколько стран: Катар, Нигерия, Тринидад и Тобаго.

Наряду с группой стран-экспортеров сжиженного природного газа сложилась и довольно постоянная группа стран-импортеров. Это, прежде всего, страны Восточной Азии - Япония (более $1 / 2$ всего мирового импорта СПГ), Республика Корея и о. Тайвань, а также страны Западной Европы - Франция, Испания, Италия, Бельгия. Обычно в эту группу включают и Турцию. Немного СПГ импортируют и США. Некоторые из этих стран - Япония, Республика Корея, о. Тайвань, ввозят природный газ только в сжиженном виде. Франция, Бельгия, не говоря уже о США, наряду с импортом СПГ, ориентируются на импорт газообразного топлива.

С географической точки зрения особый интерес представляет то обстоятельство, что отдельные районы экспорта и импорта СПГ тесно связаны друг с другом и вместе образуют международные газотранспортные системы, каждая из которых включает в себя всю производственную цепочку - от добычи природного газа до доставки его к потребителям на место назначения. К началу XXI в. в мировом хозяйстве сложились две главные газотранспортные системы - система Азиатско-Тихоокеанского региона и АфриканоЗападноевропейская система (рисунок 5).

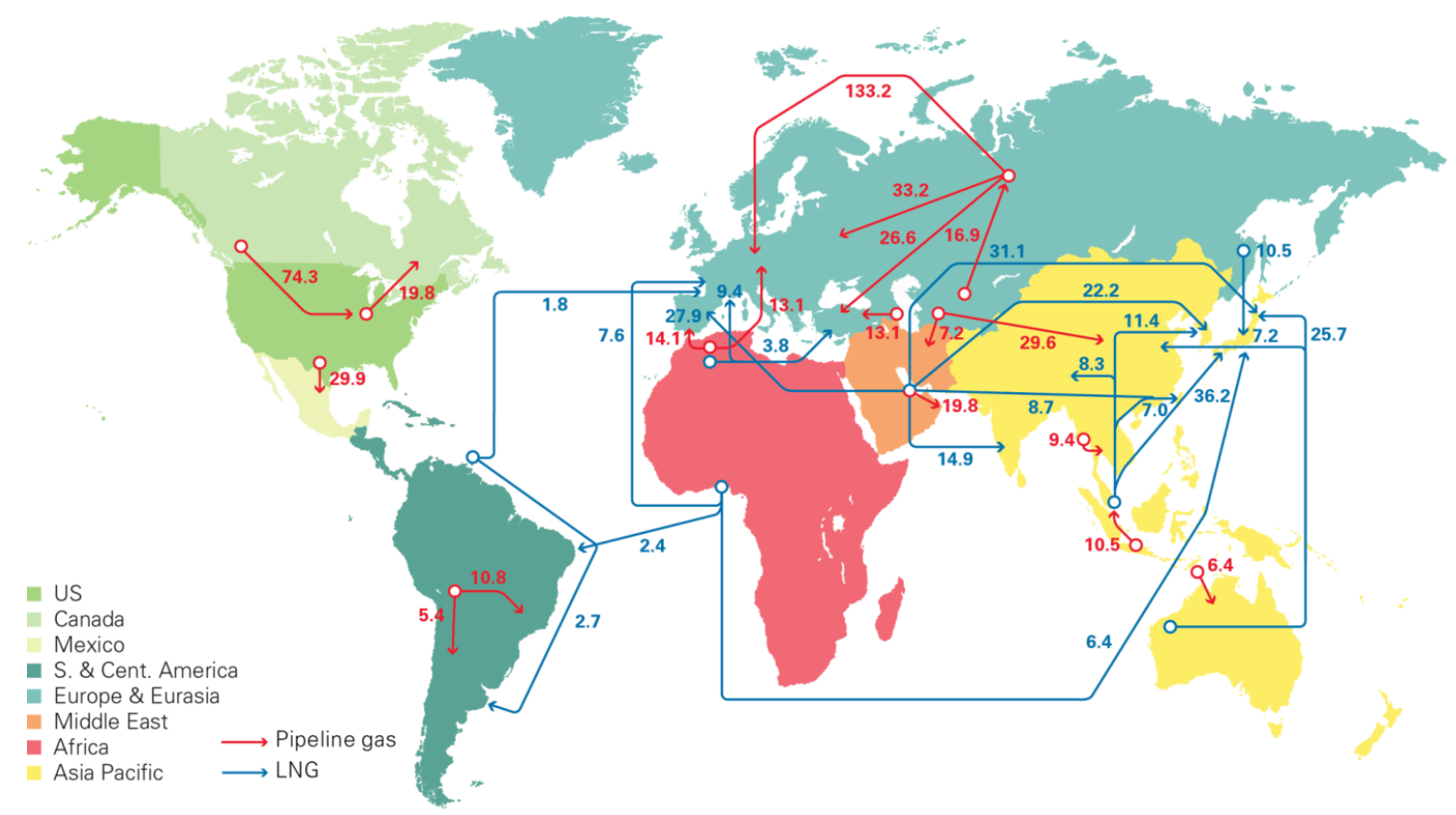

Рисунок 5 -Торговое движение газа за 2015 год, млрд м ${ }^{3}$ [4] 
Tаблица 7 - План введения в эксплуатацию новых заводов для производства СПГ [10]

\begin{tabular}{|l|c|}
\hline \multicolumn{1}{|c|}{ Объект } & $\begin{array}{c}\text { Предполагаемый } \\
\text { срок запуска }\end{array}$ \\
\hline Australia Gordon T3 & Второй квартал 2017 \\
\hline Australia Icthys & Третий квартал 2018 \\
\hline Australia Wheatstone & Второй квартал 2017 \\
\hline Australia Prelude & Первый квартал 2019 \\
\hline Russia-Yamal T1 & Четвертый квартал 2017 \\
\hline Russia-Yamal T2 & Четвертый квартал 2018 \\
\hline Russia-Yamal T3 & Четвертый квартал 2020 \\
\hline USA Sabine Pass T3 & Первый квартал 2017 \\
\hline USA Sabine Pass T4 & Первый квартал 2018 \\
\hline USA Sabine Pass T5 & Третий квартал 2019 \\
\hline USA - Corpus Christi T1 & Первый квартал 2019 \\
\hline USA - Corpus Christi T2 & Третий квартал 2019 \\
\hline USA - Corpus Christi T3 & Первый квартал 2020 \\
\hline USA - Freeport T1 & Третий квартал 2018 \\
\hline USA - Freeport T2 & Первый квартал 2019 \\
\hline USA - Freeport T3 & Третий квартал 2019 \\
\hline USA - Dominion Cove Point T1 & Первый квартал 2018 \\
\hline USA - Dominion Cove Point T2 & Второй квартал 2018 \\
\hline USA - Cameron LNG T1 & Второй квартал 2018 \\
\hline USA - Cameron LNG T2 & Третий квартал 2018 \\
\hline USA - Cameron LNG T3 & Четвертый квартал 2018 \\
\hline Cameron & Третий квартал 2017 \\
\hline Indonesia Tangguh T3 & Второй квартал 2020 \\
\hline Indonesia Floating T2 & Четвертый квартал 2018 \\
\hline
\end{tabular}

Строится большое количество новых заводов по сжижению природного газа, модернизируются уже функционирующие (таблица 7). За счет этого снабжение СПГ планируется увеличить с 350 млрд. м ${ }^{3}$ в 2016 до более 510 млрд. м³ в 2021 (рисунок 6).

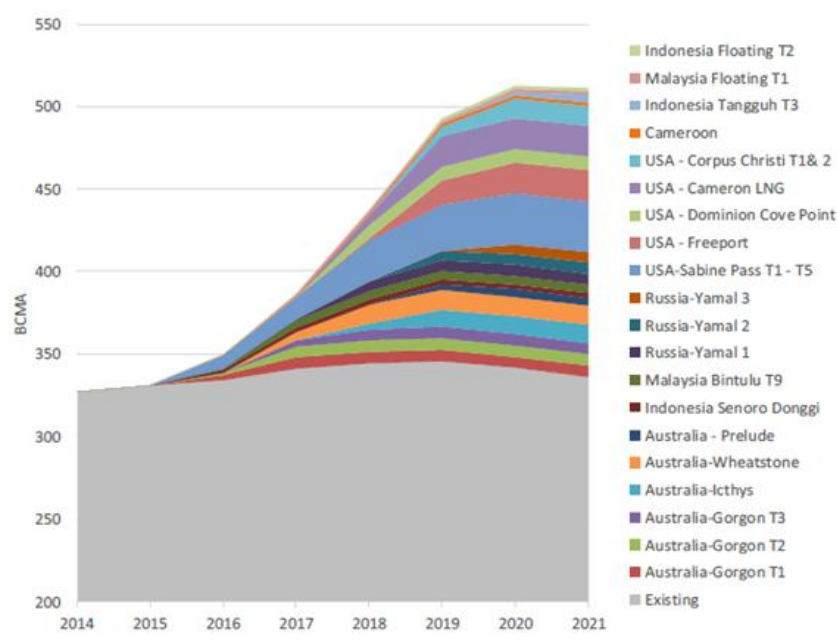

Рисунок 6 - Перспективы развития рынка СПГ до 2021 года

4.2 СПГ в Европе. Потребление газа в Европе неуклонно растет благодаря достаточно низким ценам по сравнению с альтернативами, его экологичности и планов по сокращению использования угля (особенно в Германии, Польши и Чехии) из-за активного использования в электроэнергетике, промышленности и распространения его применения в транспорте. Для замены топлива с угля на газ потребуется дополнительно 70 млрд куб. м газа в год, и часть этого спроса как раз удовлетворит СПГ.

Растет число автомобилей на газе в Европе, при этом в Италии, Франции, Германии и Нидерландах отмечается рост потребления газа именно в генерации электроэнергии. При этом Южной Европе не хватает диверсификации источников. А для того чтобы справиться с этой проблемой, Европа должна продвигать строительство новых инфраструктурных проектов, которые позволят транспортировать газ с севера на юг и с востока на запад.

В то время как Украина и Россия выясняют, сколько может стоить украинская ГТС, европейцы активно строят терминалы для приема сжиженного газа из Северной Америки. По данным [11] в 2016 г. на территории Европы находилось 26 терминалов по приему СПГ, многие из которых выполняют функцию перевалочной базы (рисунок 7). Это позволило снизить зависимость ЕС от поставок трубопроводного газа из России и из Норвегии.

Однако нужно иметь в виду, что сжиженный природный газ обычно дороже трубопроводного, поэтому он пользуется спросом только в том случае, когда традиционные поставщики не могут обеспечить необходимые объемы.

По оценке экономистов издержки добычи газа на Ближнем Востоке оцениваются на уровне 0,5 долл. США /млн. БТЕ, а в регионе Юго- Восточной Азии - 1,0 долл. США /млн. БТЕ ${ }^{1}$. Современные издержки производства СПГ в мире находятся в диапазоне 1,2-1,5 долл. США/млн. БТЕ. Оценка удельных издержек для строящихся новых мощностей находится в диапазоне от $\$ 1,20$ до \$1,90/млн БТЕ, для предполагаемых новых проектов $\$ 2,00$ - $\$ 3,20 /$ млн. БТЕ [2].

Производство сжиженного природного газа позволяет решить множество проблем, связанных с добычей природного газа в условиях арктического климата и в других труднодоступных регионах с последующей поставкой в промышленно развитые страны. В настоящее время актуальными являются исследования, направленные на снижение себестоимости СПГ, как в сфере производства, так и при его потреблении (регазификации). Для этого необходимо проведение широкого спектра исследований, направленных на разработку новых технических решений, а также совершенствование технологии производства сжиженного природного газа.

\section{5 Заключение}

Объем добычи и потребления природного газа неуклонно растет. В настоящее время используются практически все резервы его производства: сланцевый газ, попутный нефтяной и шахтный газы, Осваиваются природные и техногенные источники метана.

\footnotetext{
${ }^{1}$ БТЕ (Британская тепловая единица) или ВTU (англ., British thermal unit) - единица измерения тепловой энергии в английской системе мер. 1 ВТЕ $=1,0548$ кДж $\approx 252$ кал.

Один баррель нефти содержит $\approx 5,825 \cdot 10^{6}$ BTU (в зависимости от теплотворной способности определенного сорта нефти)
} 


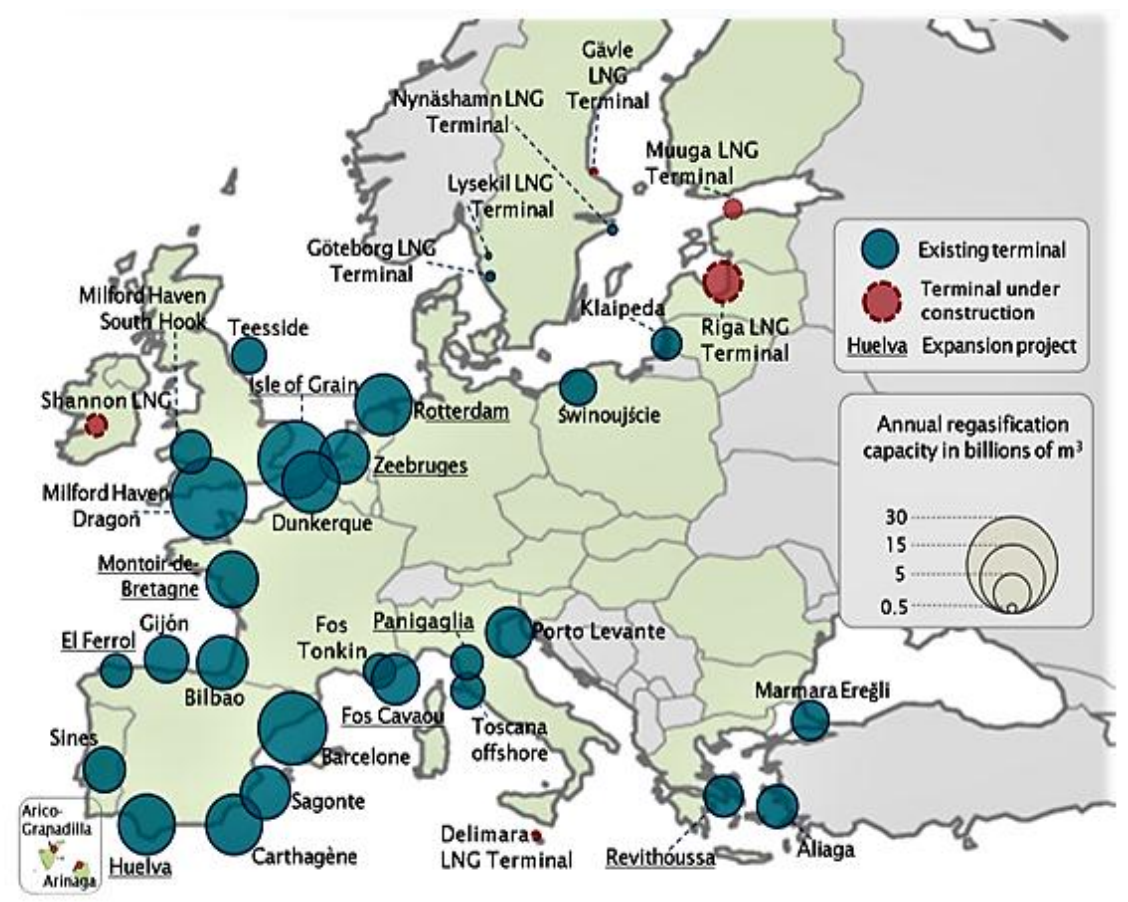

Рисунок 7 - Карта европейских терминалов СПГ на 2016 год

В качестве альтернативного газоснабжения и для поставок в труднодоступные регионы все шире используется снабжение потребителей сжиженным природным газом. Технология производства и потребления СПГ более гибкая, чем поставки трубопроводным транспортом. При этом природный газ может быть любого происхождения (ПГ, СГ и т.п.), добываться даже в труднодоступных областях земного шара. При наличии минизаводов по производству СПГ он может транспортироваться на уже развернутые или строящиеся терминалы по регазификации и снабжению потребителей.

Несмотря на относительную дороговизну сжижения ПГ, с увеличением объемов промышленного производства его потребление будет неуклонно расти. Следовательно, исследования технологий сжижения и регазификации природного газа с целью снижения их удельного энергопотребления в ближайшие десятилетия будут исключительно актуальными.

\section{Литература}

1. European Commission (2016) DG Energy, Market Observatory for Energy. Vol 9, iss.1, 3-18.

2. Фейгин В.И., Иванов Н.А., Ревенков В.И. (2012) Рынок сжиженного природного газа: мир и Россия. Семинар. Институт Энергетики и Финансов. Москва. 31 с. URL: http://www.fief.ru/presentation/read.142.htm

3. Фитерер Е.П. (2016) Природный газ в промышленности. Томский Политехнический Университет. 16 с. URL: http://docplayer.ru/28627594-Prirodnyy-gaza-vpromyshlennosti.html
4. BP Statistical Review of World Energy 2016. C. 20-29. URL: https://www.bp.com/content/dam/bp/pdf/energyeconomics/statistical-review-2016/bp-statistical-review-ofworld-energy-2016-full-report.pdf/ (Date of access: Jan 2017)

5. An Assessment of the Gas and Oil Pipelines in Europe (2009) Directorate General for Internal Policies. Policy Department 11.2009, 7-10.

6. World LNG Plants and Terminals outlook 2016. Global LNG info [Electronic source]. URL: http://www.globallnginfo.com (Date of access: Jan 2017)

7. Высоцкий В.И., Фельдман С.Л. Нефтегазовая промышленность мира Ссправочно информационоый обзор. Приложение 4. - ОАО «ВНИИЗАРУБЕЖГЕОЛОГИЯ». - 2014. С 60.

8. Максаковский В.П. Географическая картина мира: [в 2 кн.]. - Москва: Дрофа. Кн. 1 : Общая характеристика мира. $-2009 .-495$ с.

9. Высоцкий В.И., Фельдман С.Л. Нефтегазовая промышленность мира. Справочно-информационный обзор. - ОАО «ВНИИЗАРУБЕЖНЕФТЕГАЗ» - 2014. $98 \mathrm{c}$.

10. Rogers H. The Forthcoming LNG Supply Wave: A case of "Crying Wolf". The Oxford Institute for Energy Studies. URL: https://www.oxfordenergy.org/publications/ forthcoming-lng-supply-wave-case-crying-wolf 11. International Group of Liquefied Naturals Gas Importers (GIIGNL) [Electronic source]. URL: http://www.giignl.org (Date of access: Jan 2017)

Отримана в редакції 22.02.2017, прийнята до друку 25.04.2017 


\title{
Liquefied Gas - Alternative Source of Natural Gas Supply to the World's Industrialized Regions
}

\author{
T. V. Diachenko ${ }^{1}$, V. N. Artiukh ${ }^{2}$, A. S. Titlov ${ }^{3}$ \\ Odessa National Academy of Food Technologies, 112 Kanatna str, Odesa, 65039, Ukraine \\ e-mail: 1diachenko.tetiana.v@gmail.com, ${ }^{2}$ vartiuh@outlook.com, ${ }^{3}$ titlov1959@gmail.com \\ ORCID: ${ }^{1}$ http://orcid.org/0000-0001-9275-187X; ${ }^{2}$ http://orcid.org/0000-0002-1751-7933; ${ }^{3}$ http://orcid.org/0000-0003-1908-5713
}

\begin{abstract}
Natural gas is an important energy source in the overall energy system. Liquefied natural gas is one of the options for delivery to hard-to-reach regions. This article reviews the world natural gas market: reserves, production, consumption. More specifically, attention was paid to Europe, the issue of its infrastructure and market was touched. Examples of successful use of liquefied natural gas in some European countries and new potential liquefied natural gas consumers are given.
\end{abstract}

Key words: Natural Gas; Shale gas; Natural gas market; Liquefied natural gas

\section{References}

1. European Commission (2016) DG Energy, Market Observatory for Energy. Vol 9, iss.1, 3-18.

2. Feygin V.I., Ivanov N.A., Revenkov V.I. (2012) Ryinok szhizhennogo prirodnogo gaza: mir i Rossiya. Se-minar. Institut Energetiki i Finansov. Moskva. 31 c. URL: http://www.fief.ru/presentation/read.142.htm (in Russian)

3. Fiterer E.P. (2016) Prirodnyiy gaz v promyishlen-nosti. Tomskiy Politehnicheskiy Universitet. 16 c. URL: http://docplayer.ru/28627594-Prirodnyy-gaza-vpromyshlennosti.html (in Russian)

4. BP Statistical Review of World Energy 2016. Pp. 20-29. URL: https://www.bp.com/content/dam/bp/pdf/energyeconomics/statistical-review-2016/bp-statistical-review-ofworld-energy-2016-full-report.pdf/ (Date of access: Jan 2017)

5. An Assessment of the Gas and Oil Pipelines in Europe (2009) Directorate General for Internal Policies. Policy Department 11.2009, 7-10.
6. World LNG Plants and Terminals outlook 2016. Global LNG info [Electronic source]. URL: http://www.globallnginfo.com (Date of access: Jan 2017)

7. Vyisotskiy V.I., Feldman S.L. (2014) Neftegazovaya promyishlennost mira Sspravochno informatsionoyiy obzor. VNIIZARUBEZhGEOLOGIYA. 60 p. (in Russian)

8. Maksakovskiy V.P. (2009) Geograficheskaya kartina mira. Moskva: Drofa. 495 p. (in Russian)

9. Vyisotskiy V.I., Feldman S.L. (2014) Neftegazovaya promyishlennost mira. Spravochno-informatsionnyiy obzor. VNIIZARUBEZhNEFTEGAZ. 98 p. (in Russian)

10. Rogers H. The Forthcoming LNG Supply Wave: A case of "Crying Wolf". The Oxford Institute for Energy Studies. URL: https://www.oxfordenergy.org/publications/ forthcoming-lng-supply-wave-case-crying-wolf

11. International Group of Liquefied Naturals Gas Importers (GIIGNL) [Electronic source]. URL: http://www.giignl.org (Date of access: Jan 2017) 